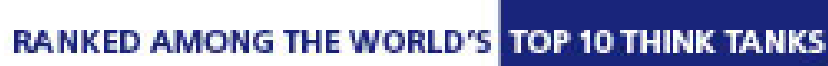

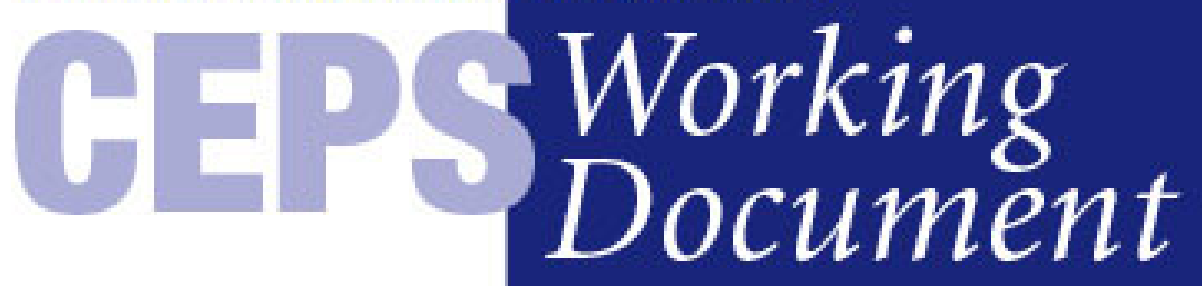

Thinking ahead for Europe

\title{
Is the euro really a 'teuro'? Effects of introducing the euro on prices of everyday non-tradables in Slovakia
}

\section{CEPS Working Document No. 339/ November 2010}

\author{
Miroslav Beblavý
}

\begin{abstract}
This paper looks at the Slovak experience with euro adoption from the point of view of perceived versus actual inflation and with a focus on a specific set of non-tradable prices. It examines whether Slovak consumers experienced or perceived (or both) an unusual price jump at the time of euro adoption and the possible explanations for such a phenomenon.

Comparing the Slovak experience with the creation of the eurozone, and also with adoption of the single currency in Cyprus, Malta and Slovenia, we find that in terms of both reality and perceptions of general price movements every adoption is different. For Slovakia, euro adoption came at a time of disinflation, which consumers actually experienced, so there does not seem to be any overall perception that it is a 'teuro' (from teuer, meaning 'expensive' in German). We can nonetheless observe high inflation for nontradables at both the macro and micro levels, linked not only to the Slovak strategy of nominal currency appreciation prior to eurozone entry but also to the changeover itself.
\end{abstract}

CEPS Working Documents are intended to give an indication of work being conducted within CEPS research programmes and to stimulate reactions from other experts in the field. Unless otherwise indicated, the views expressed are attributable only to the authors in a personal capacity and not to any institution with which they are associated.

ISBN 978-94-6138-064-7

Available for free downloading from the CEPS website (http:/ / www.ceps.eu)

(c) Centre for European Policy Studies, 2010 


\section{Contents}

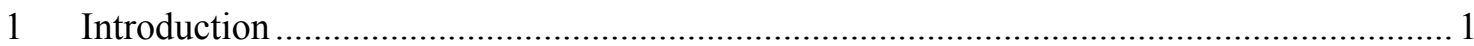

2 Inflation shocks during euro adoption - Survey of literature ............................................ 3

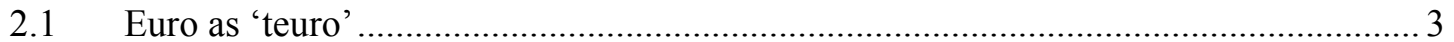

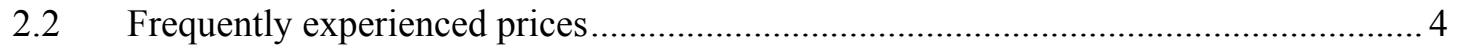

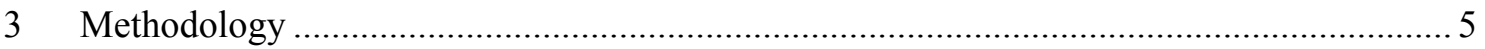

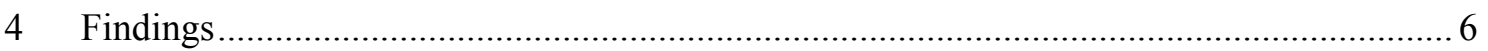

4.1 Inflation in Slovakia and the euro area: The overall HICP

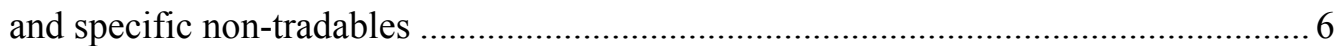

4.2 Accounting for the Balassa-Samuelson effect ......................................................... 10

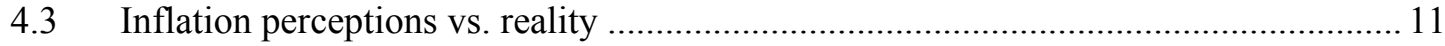

4.4 Analysis of the price data at the micro level and comparison with national price data .............................................................................................. 14

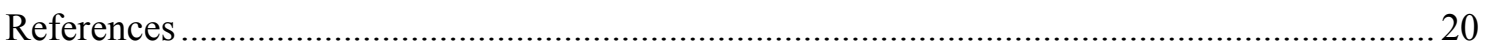

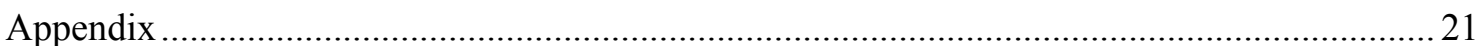




\section{IS THE EURO REALLY A 'TEURO'? \\ EFFECTS OF INTRODUCING THE EURO ON PRICES OF EVERYDAY NON-TRADABLES IN SLOVAKIA \\ CEPS WORKING DOCUMENT NO. 339/NOVEMBER 2010 \\ Miroslav BeblavÝ*}

\section{Introduction}

When the euro notes and coins were originally introduced in January 2002, consumers in the member states of the eurozone experienced a sharp spike in perceived inflation, which translated into a permanent perception that the switch to the new currency was associated with a one-time inflation shock. As evidence of it, the synthetic indicator of perceived inflation over the previous 12 months compiled by the European Commission from consumer surveys showed a jump from 27 in December 2001 to 60 in September 2002 and remained above 50 for most of 2002. The most succinct summary of this view was coined in Germany, where the euro was promptly dubbed 'teuro' (from teuer, meaning 'expensive' in German).

For consumer prices as a whole, the perception was largely disproved by the actual data on the development of consumer prices during the relevant period. Prices in January 2002 rose by $0.09 \%$ in the eurozone according to the Harmonised Indices of Consumer Prices (HICP) and the annual inflation rate during 2002 was also similar to 2001 and 2003, oscillating between $2 \%$ and $3 \%$ (although there was an unusual jump at the beginning of 2002, attributed mainly to weather). Therefore, the explanations of discrepancies between the perceived and the actual inflation tended to focus on either purely psychological interpretations of how individuals could experience higher inflation at the time of a change in currencies without any basis in reality, or interpretations combining higher-than-normal changes in specific prices, which are likely to form anchors of consumer experiences, with psychologically-based misconceptions.

Both explanations build on the fact that eurozone consumers perceived differentiated levels of price hikes according to the kind of product and establishment. If we look at Table 1, we can see a certain subset of frequently purchased non-tradables (restaurants, taxis and hairdressers) that could possibly have been behind the teuro phenomenon.

\footnotetext{
* Miroslav Beblavý is Associate Professor at the Institute of Public Policy and Economics, Comenius University, Bratislava, Senior Research Fellow at the Center for European Policy Studies, Brussels, The author would like to thank David Cobham for the discussion that led to this paper, Hans Wolfgang Brachinger for agreeing to be the discussant for this paper and his patience in waiting for the draft, and Soňa Urbančíková and Katarína Lovrantová for invaluable help in preparing the paper. The final version of this paper is due to appear in the forthcoming book by M. Beblavý, D. Cobham and L. Ódor (eds), The Euro Area and the Financial Crisis, Cambridge: Cambridge University Press.
} 
Table 1. Answers by respondents in the eurozone as a whole to the question, "For each of the following, do you personally have the feeling that, in the conversion to the euro in area $X$, prices have been..." (\%)

\begin{tabular}{|l|r|r|r|r|r|r|}
\hline & $\begin{array}{r}\text { Always } \\
\text { rounde } \\
\text { d up }\end{array}$ & $\begin{array}{r}\text { Most } \\
\text { often } \\
\text { rounded } \\
\text { up }\end{array}$ & $\begin{array}{r}\text { Most often } \\
\text { rounded } \\
\text { down }\end{array}$ & $\begin{array}{r}\text { Always } \\
\text { rounded } \\
\text { down }\end{array}$ & $\begin{array}{r}\text { All in all, they } \\
\text { ancel each } \\
\text { other out }\end{array}$ & $\begin{array}{r}\text { Do } \\
\text { not } \\
\text { know }\end{array}$ \\
\hline $\begin{array}{l}\text { Restaurants/ } \\
\text { cafés }\end{array}$ & 40.8 & 43.4 & 3.2 & 0.4 & 4.2 & 8 \\
\hline $\begin{array}{l}\text { Services } \\
\text { hairdressers/ } \\
\text { taxis) }\end{array}$ & 36.5 & 42.4 & 3.8 & 0.8 & 6.2 & 10.4 \\
\hline $\begin{array}{l}\text { Small food } \\
\text { shops }\end{array}$ & 30.3 & 48.4 & 4.1 & 0.5 & 8.6 & 8.2 \\
\hline $\begin{array}{l}\text { Other small } \\
\text { shops }\end{array}$ & 28.4 & 47.1 & 4.8 & 0.6 & 8.6 & 10.4 \\
\hline $\begin{array}{l}\text { Cinemas/ } \\
\text { swimming } \\
\text { pools }\end{array}$ & 25.9 & 36.2 & 4.3 & 1.3 & 7.5 & 24.8 \\
\hline Supermarkets & 24.2 & 43.7 & 11.1 & 2 & 15 & 4.1 \\
\hline $\begin{array}{l}\text { Public } \\
\text { transport }\end{array}$ & 24.1 & 31.2 & 8.7 & 1.4 & 11.6 & 22.9 \\
\hline
\end{tabular}

Source: European Commission, Eurobarometer No. 171, Brussels, May 2002.

The introduction of the euro in Slovakia in 2009 is an opportunity to revisit this discussion in a new environment.

In the context of inflation perceptions and realities, Slovakia presents an interesting case. Slovakia has had two decades of experience with rigorous monetary policy and moderate inflation, and also with repeated price shocks stemming from changes in administratively-set prices, indirect taxes and other transition phenomena. Like the Czech Republic, and unlike Hungary and Poland, it has had 'German' monetary policy, but without the German experience of monetary stability.

Slovakia also joined the euro at the end of a long period of economic boom, but just as the global financial and economic crisis fully hit European economies. It adopted the single currency with a very strong exchange rate based on the assumption of further rapid growth, indeed a possibility of overheating after the switchover. There was also the expectation that the lower price level and the Balassa-Samuelson effect would lead to higher inflation once the option of adjusting the real effective exchange rate through nominal appreciation was exhausted.

This paper looks at the Slovak experience with euro adoption from the point of view of perceived versus actual inflation, with a focus on a specific set of non-tradable prices. It uses both official price data and an original data set of prices at the enterprise level, examining whether Slovak consumers experienced an unusual price jump at the time of euro adoption. 
Additionally, this paper proposes what could be a possible explanation for such a phenomenon, building on the literature concerning previous instances of switches to the single currency.

The paper starts with a review of the state of the art in the area and then presents the methodology of the paper. It continues with empirical findings, dealing in turn with the HICP data, data on inflation perceptions and expectations, and the enterprise-level price data and their interpretation. Some preliminary conclusions are presented at the end.

\section{Inflation shocks during euro adoption - Survey of literature}

In this section, we briefly look at the literature dealing with the two topics most relevant to the paper. The first and most important body of literature deals with the topic of why the euro's introduction was associated with an inflation hike in the minds of consumers across the eurozone. This sets the stage for our own research on the introduction of the single currency in Slovakia. The second topic concerns the frequency and (a)symmetry of price changes at the enterprise level and should enable us to better place our micro research in the context of the observed phenomenon.

\subsection{Euro as 'teuro'}

Theoretically, the euro changeover should have had almost no effect on consumer behaviour: the exchange rates were fixed long before the new currency was introduced (Mastrobuoni, 2004), and in the 12 months prior to May 2002 the European inflation rate exhibited the same level as had been recorded right before the introduction of the euro notes and coins in the eurozone (Brachinger, 2006). Even though a strong increase in overall inflation in the eurozone was observed at the beginning of 2002, this was, as the European Central Bank (ECB) reported, largely owing to exceptional and short-lived factors, such as adverse weather conditions in some parts of the euro area (ECB, 2002, quoted in Ercolani and Dutta, 2007, p. 384).

Prior to mid-2001 in all EU countries, the gap between perceived and actual inflation was close to zero. The perception gap appeared in all EU countries only a few months before and after the euro changeover. In the countries that did not join the euro area, the gap trend remained close to zero, implying that the departure of perceived inflation from actual inflation was indeed related to the introduction of the euro (Hufner and Koske, 2008).

Brachinger (2004, 2005a and 2005b) developed the so-called 'index of perceived inflation', showing that in the period around the introduction of the euro notes and coins, the average perceived inflation in Germany was approximately four times higher than the official inflation rate (Brachinger, 2006). Mastrobuoni's (2004) findings, based on Eurostat and a consumer survey, present a similar overall picture, with the mean difference between standardised perceived and actual inflation oscillating between 0.32 and 1.23 among the countries, after the euro changeover. Additionally, Brachinger (2005b) claims that based on the theory of loss aversion, customers' perceptions about inflation are more influenced by price rises than by price decreases because they weigh the purchasing power loss greater than purchasing power gain.

Importantly though, while showing that the perception of increased inflation was markedly overrated, authors simultaneously stress that frequent - albeit moderate - price increases did occur at the introduction of the new currency. Stix (2005) notes that most of the goods contained in the micro and mini baskets became more expensive, which, in line with the ECB's 2002 conjecture that after the introduction of the euro, consumers based their estimation of price increases on goods that are purchased more frequently, partly explains the bias of the euro towards the teuro (Kirchler, 2005).

Mastrobuoni (2004) provides a similar explanation, but rather than presenting it as a partial conclusion, he uses it as a starting point to analyse the causes and differences in inflation 
patterns for different goods. He does this on the premise that "the changeover to a new currency reduces the information about prices available to the customer", suggesting that "the reason for higher inflation among cheap goods is the cost of obtaining information". The price growth is therefore "correlated with consumers' ability to adapt to the new currency" - a theory confirmed by the fact that the three countries with the strongest euro effect on prices (Spain, Italy and France) were the countries with the highest percentage of consumers who tended to judge the price appropriateness using their old currency.

Even though Mastrobuoni uses Eurostat's monthly HICP (in combination with the data collected by the Economist Intelligence Unit), he stresses the bias of relying solely upon the macro indices in testing the level of a possibly euro-changeover-induced inflation, perceived or real. Brachinger (2006) similarly points out that the major drawback of "an expenditureweighted price index such as the CPI is [that it is] insensitive to the appearance of inordinately high price increases of frequently purchased goods and tends to mask such inflation structures".

Similar methodological drawbacks are a starting point of the analysis of Ercolani and Dutta (2007), who hypothesise that "the euro changeover generated inflation that was not detected by official statistics". While the 2002 ECB statement assured that "no evidence of a eurochangeover-induced increase in aggregate prices could be found and that any variation in food prices was due to seasonal factors", it also conceded there may have been price increases for some specific items in the service sectors that "could have been related to the changeover" (quoted in ibid., p. 384). What the authors thus subsequently attempt to show is that the overall "weak evidence of a slight temporary increase in aggregate inflation in January 2002 for the countries that did join the euro" played out variably at the individual level of specific sectoral items. At that level, the euro-changeover-induced price changes ranged from statistically insignificant and quantitatively small to quantitatively large and statistically crucial - as was specifically the case in the restaurant sector.

The analysis in this paper focuses on micro data collection as a key to observing the varying price movements for non-tradables. Combining micro and macro data and indices offers an overall picture of the euro adoption process in Slovakia.

\subsection{Frequently experienced prices}

Inevitably related to the effects of euro changeover as documented by this paper is the experience of price-setting behaviour at the level of firms and enterprises, concerning which the following aspects are of particular relevance:

- the frequency of price reviews/changes,

- the scope of price changes, and

- the symmetry of this behaviour.

Past surveys have shown that the vast majority of firms review their prices a maximum of 3 times per year, that is $57 \%$ of the euro area as a whole, while $26 \%$ review prices more than 12 times a year, and $17 \%$ do so 4 to 11 times in a year (Fabiani et al., 2005). The frequency of the price change, though, is relatively low: micro evidence of the Inflation Persistence Network (IPN) shows that prices in sectors covered by the consumer price index remain unchanged on average for 4 to 5 quarters. In addition, the frequency is somewhat lower in the retail sector compared with the producer sector, where the median firm changes the price of its goods once a year. It has also been found that prices change less frequently for products with a larger share of labour input and with a smaller share of intermediate energy inputs (Altissimo, Ehrman and Smets, 2006). 
The price-setting behaviour is thus heterogeneous across the product categories: the IPN micro evidence shows that while changes are very frequent for energy and unprocessed food $(78.0 \%$ and $28.3 \%$, respectively), they are relatively infrequent for non-energy industrial goods and especially services (9.2\% and 5.6\%, respectively) (Altissimo, Ehrman and Smets, 2006).

Looking at the magnitude of price changes, it turns out that price increases as well as decreases are sizeable compared with the inflation rate. Price reductions and price increases have a similar order of magnitude, although price reductions are on average larger: the average price increase is found to be in the order of $8 \%$ and the average price decrease slightly larger than $10 \%$ (ibid.).

Some sectors - unprocessed food, processed food and energy - are characterised by almost perfect symmetry between price increases and price decreases; the difference is much larger in the services sector, where an asymmetry exists between the frequency of increases and decreases as only two price changes out of ten are price decreases (ibid.).

\section{Methodology}

This paper is based on comparing price datasets at both the macro and micro levels. In addition to the general price index, we focus on prices in restaurants/cafés, hairdressing salons, and for taxi services.

At the macro level, we compare HICP data collected for Eurostat by the national statistical agencies for three entities - the euro area, Slovakia and the Czech Republic. We use overall inflation as well as three subsets that are closest to what we measure in the micro data:

- $\quad$ passenger transport by road (reference group for taxis);

- restaurants, cafés and the like (reference group for all meals and drinks served in restaurants); and

- $\quad$ hairdressing salons and personal grooming establishments (reference group for a haircut).

At the macro level, we also utilise data on perceptions based on consumer surveys collected by Eurostat on a monthly basis. The time series measures consumer experience with inflation (based on the question, "How do you think that consumer prices have developed over the last 12 months?"). In this case, we also use data for other new member states that have adopted the euro (Cyprus, Malta and Slovenia).

The third set of macro-level data comes from Eurobarometer surveys specifically concerning the introduction of the euro. In the case of Slovakia, these are survey nos. 240, 249 and $259 .{ }^{1}$ We compare answers from those surveys with the results of similar surveys done at the introduction of the euro in Slovenia in 2007 and in Cyprus and Malta in 2008, as well as the introduction in the original euro-12 countries in 2002.

At the micro level, we compare datasets collected specifically for this research in Bratislava, the capital of Slovakia, and Brno, the second largest city in the Czech Republic. The reason for choosing Brno as an analogous case study to Bratislava is the shared Czecho-Slovak history, a comparable size and the geographical proximity $(130 \mathrm{~km})$ of the two cities. In this sense, Brno and at the macro level, the Czech Republic serves as a 'control group' for Bratislava and Slovakia. The Czech Republic has not adopted the euro or entered the exchange rate mechanism (ERM-2) yet and its currency floats vis-à-vis other currencies.

\footnotetext{
${ }^{1}$ See European Commission, Preparing for the euro: Survey of Slovak enterprises, Flash Eurobarometer No. 240, Brussels, July 2008; European Commission, Introduction of the euro in Slovakia, Flash Eurobarometer No. 249, Brussels, November 2008; and European Commission, Euro introduction in Slovakia: Ex post citizen survey, Flash Eurobarometer No. 259, Brussels, March 2009.
} 
At the micro level, we collected data for eight specific services in three categories. For cafés and restaurants, we collected the most common main course and side dish listed on all menus schnitzel and boiled potatoes - and the two most frequently drunk kinds of coffee - cappuccino and Viennese coffee. For hair salons, we collected one dataset on basic haircut prices (for a female customer, washing, cutting and styling the hair). For taxis, we collected the price for flagging a taxi, a price per $1 \mathrm{~km}$ and a price per 1 min of waiting.

The micro-level datasets were collected in two snapshots. The first one took place in July 2008 and the second one in July 2009. In both cases, the prices of specific services were collected from individual service providers based on a combination of prices posted on the Internet and prices provided on request by telephone. In the case of Slovakia, the euro prices from July 2009 were compared with the Slovak koruna prices from July 2008 using the official final conversion rate of 30.126 koruna $=1$ euro. But the choice of the exchange rate would not have had any major influence on the inflation developments anyway, for by July 2008 the final conversion rate had already been announced and the exchange rate only subsequently converged on it (30.3 koruna per euro), with the difference was caused solely by remaining interest rate differentials.

The two periods were chosen to eliminate seasonal effects and to capture the overall effect of transition to the euro. In other words, the aim was not to measure price jumps (or lack thereof) exactly at the time of the switch, but to capture the overall change associated with euro adoption. The net was thus cast relatively widely, in order to measure price developments for the period of six months prior to and after the change.

The data analysis proceeds in the following steps. First, we begin by examining the actual inflation data at the macro level, comparing developments in the HICP for the euro area, Slovakia and the Czech Republic for all prices and for the three subsets identified above. The objective of the initial exercise is to provide a basic picture of the price developments in Slovakia during the 2000 s and particularly during the run-up to euro adoption - with regard to both general prices and those that are the specific focus of the paper.

This is followed in the second step by the analysis of perceptions, using similar tools for the time series analysis, but complementing them with comparison of one-time data gleaned from the flash Eurobarometer surveys.

In the third part of the data analysis, we look at the micro data from Bratislava and Brno. We examine the distribution of the price increases through an analysis of mean and variance and by comparing the values for each item for the two cities. We then compare the conclusions from the micro data with the development of reference prices in the same period at the national level to note any discrepancies.

\section{Findings}

\subsection{Inflation in Slovakia and the euro area: The overall HICP and specific non-tradables}

As we can see in Figure 1, prices in Slovakia have oscillated markedly during the last decade, with annual inflation reaching almost $10 \%$ in 2003 , but then dropping steadily and eventually falling below $1 \%$ in 2010 . Yet this turbulence relative to euro area inflation was largely induced by administrative steps during the 1999-2001 period and the 2003-04 period, particularly several steep increases in VAT and excise taxes as well as direct increases in administered prices. Once the effects of these policy measures played had out by 2005 , Slovak inflation decreased to $2 \%$ and oscillated between $2 \%$ and $5 \%$ until the adoption of the single currency in January 2009. At the end of 2006, Slovak inflation began to closely track overall eurozone inflation and did not begin to diverge again until mid-2009, when it temporarily spiked. 
Figure 1. HICP inflation in the euro area, the Czech Republic and Slovakia, 2001-10 (y-o-y) (\%)

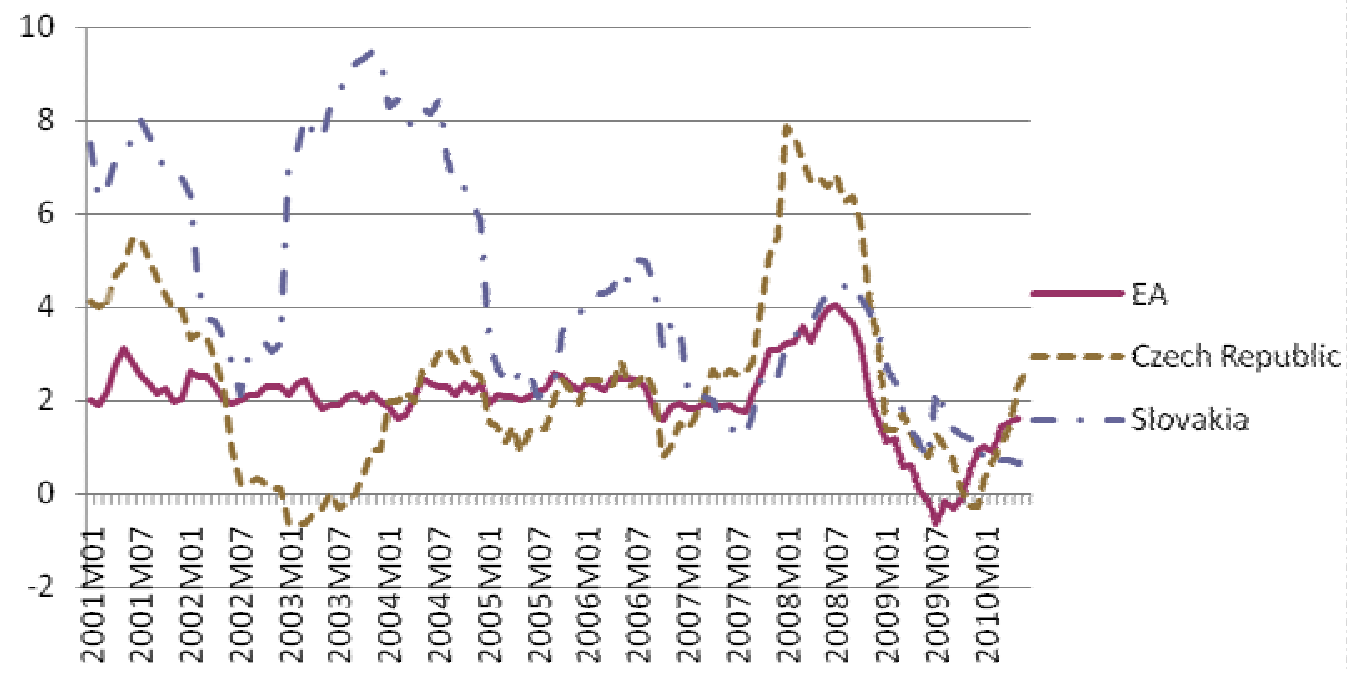

Source: Eurostat.

With regard to non-tradables, notably the services analysed in this paper, the picture of inflation convergence with the euro is not equally straightforward.

Starting with price developments for passenger transport by road, we can observe three sharp spikes in inflation (Figure 2). Two of them - in 2001 and 2003 - are directly tied to policy measures (tax changes and price deregulation); however, there is no such obvious explanation for the spike preceding and following the introduction of the euro. After remaining at the 5-6\% level during much of 2006 and 2007, the prices of passenger transport by road grew dramatically in 2008, with year-on-year inflation reaching $20 \%$ at the end of 2008 and then remaining at around $15 \%$ until the end of 2009 . Oil prices provide just part of the answer as evidenced by only weak rises in euro-area passenger transport prices during the same period. In addition is the fact that Czech prices did not follow the same pattern (after a spike in 2008 caused by tax measures, this type of inflation dropped dramatically by the end of 2008 towards the eurozone level). 
Figure 2. HICP inflation for passenger transport - Eurozone, Czech Republic and Slovakia, 2000-10 (\%)

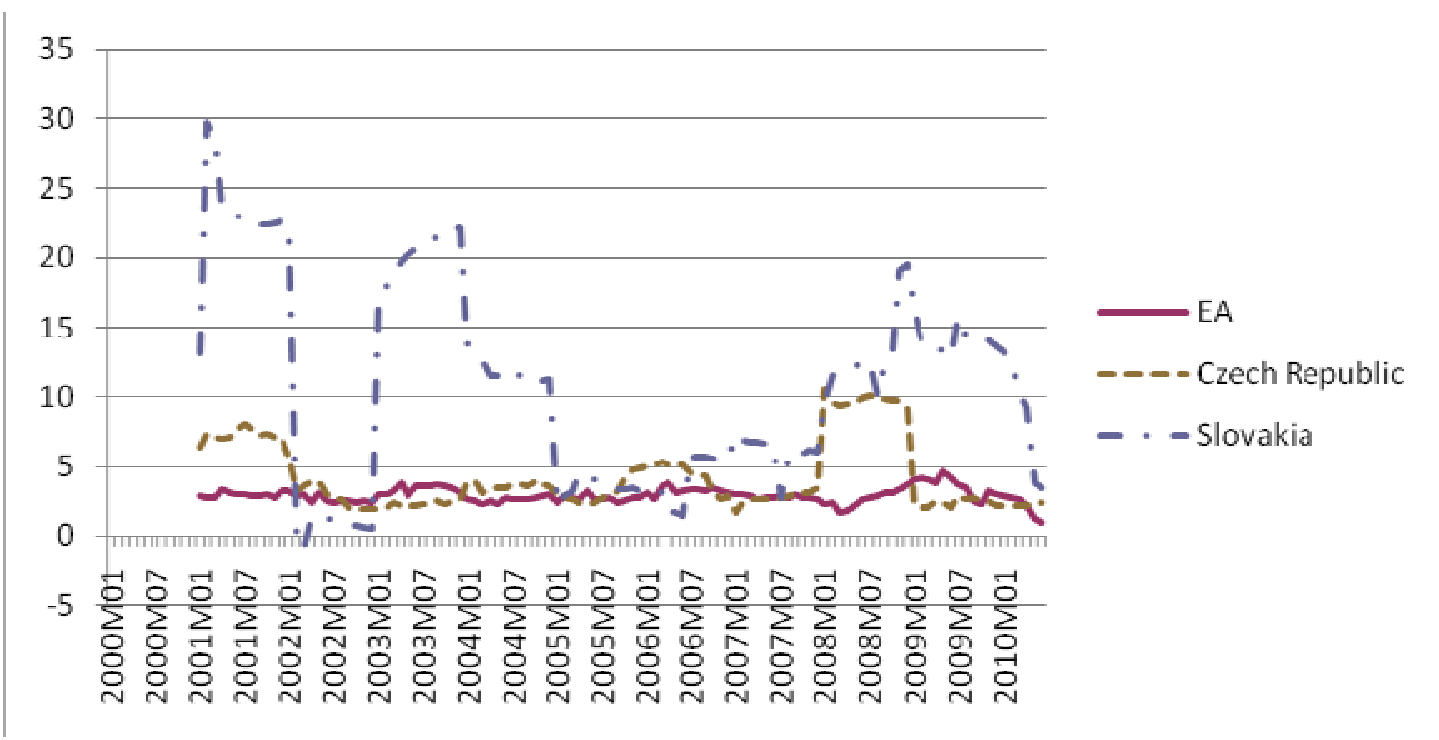

Source: Eurostat.

Similar observations can be made for prices in restaurants, cafés and comparable establishments. As tracked in Figure 3, prices also began to diverge from the eurozone at the end of 2007 and remained at unusually high levels during 2008 and 2009, starting to drop in late 2009. Again, the Czech case confirms the Slovak anomaly, since Czech prices rose during 2008 only as a result of a clearly identifiable set of tax changes, and once these played out, prices rapidly decreased and returned to close to the eurozone level. In the Slovak case, there is a particularly sharp 12-month hike between July 2008 and 2009, in the period following confirmation of the future entry.

Figure 3. HICP inflation in restaurants, cafés and similar establishments - Eurozone, Czech Republic and Slovakia, 2000-10 (\%)

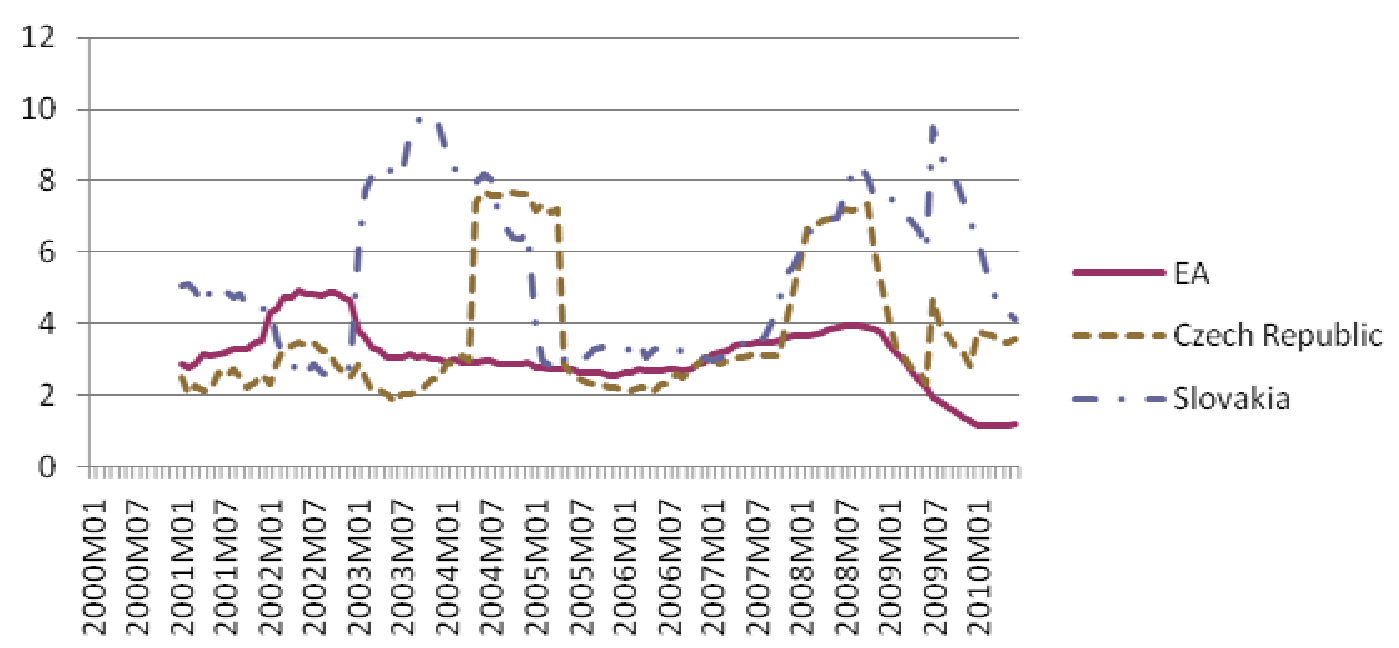

Source: Eurostat. 
Finally, the price developments for hairdressing salons and personal grooming establishments present an identical picture, including the unusual spike between July 2008 and July 2009 (Figure 4).

Figure 4. HICP inflation in hairdressing salons and personal grooming establishments Eurozone, Czech Republic and Slovakia, 2000-10 (\%)

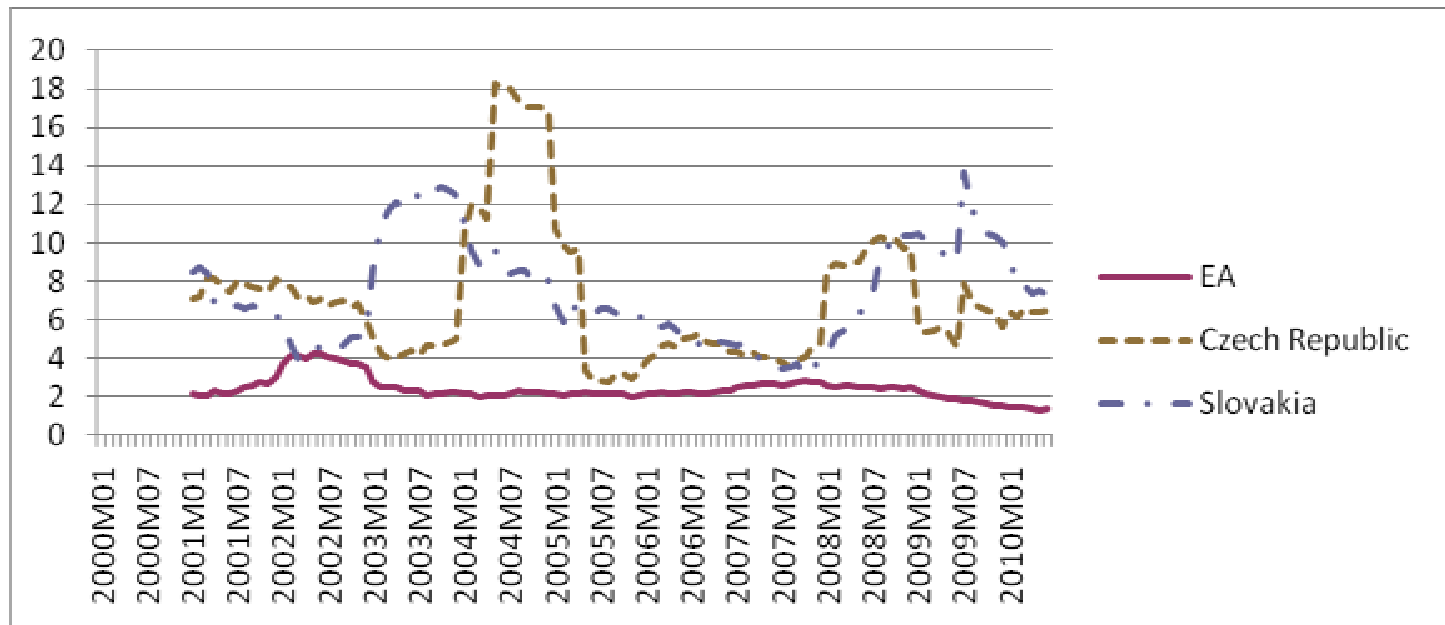

Source: Eurostat.

The rapid increases could of course be a peculiarity of the Slovak development. Given, however, that these prices had already been identified as mostly 'rounded up' in 2002 during the launch of the euro bank notes and coins, it is worth examining whether we do observe a more general trend here.

Table 2 presents a summary of price developments during the period surrounding euro adoption. It examines inflation for a given bundle of goods and services if we compare prices in the July following euro adoption in a given country with the July of the previous year. The years are 2001 and 2002 for the original euro-area countries, 2006 and 2007 for Slovenia, 2007 and 2008 for Cyprus and Malta, and 2008 and 2009 for Slovakia. It also compares inflation for a given subset of prices with overall inflation, showing the differential between general inflation and the specific bundle.

Table 2. Inflation in selected areas, in the July after euro adoption vs. the July prior to euro adoption

\begin{tabular}{|l|r|r|r|r|r|r|r|r|r|r|r|}
\hline & $\begin{array}{r}\text { Overall } \\
\text { inflation }\end{array}$ & $\begin{array}{r}\text { Passenger } \\
\text { transport } \\
\text { by road }\end{array}$ & $\Delta$ & $\begin{array}{r}\text { Restaurants, } \\
\text { cafés, etc. }\end{array}$ & $\Delta$ & $\begin{array}{r}\text { Hair- } \\
\text { dressing }\end{array}$ & $\Delta$ & Goods & $\Delta$ & Services & $\Delta$ \\
\hline Euro area & 2.02 & 2.38 & 0.36 & 4.81 & 2.79 & 4.03 & 2.01 & 1.15 & -0.87 & 3.23 & 1.21 \\
\hline Cyprus & 5.34 & 9.46 & 4.12 & 6.34 & 1 & 6.94 & 1.6 & 5.92 & 0.58 & 4.43 & -0.91 \\
\hline Malta & 5.6 & 1.48 & -4.12 & 5.37 & -0.23 & 2.07 & -3.53 & 5.64 & 0.04 & 5.53 & -0.07 \\
\hline Slovenia & 3.97 & 2.56 & -1.41 & 8.99 & 5.02 & 5.93 & 1.96 & 3.39 & -0.58 & 5.09 & 1.12 \\
\hline Slovakia & 0.61 & 12.44 & 11.83 & 5.41 & 4.8 & 8.13 & 7.52 & -1.37 & -1.98 & 4.75 & 4.14 \\
\hline
\end{tabular}

Source: Author's calculations based on Eurostat data. 
As we can see, Slovakia exhibits obvious anomalies compared with other countries in this respect. This is true for non-tradables in general (proxied by the prices of services), for which the inflation in Slovakia in the period immediately before and after euro adoption was 4.14 percentage points higher than general inflation, whereas in other countries, the differential was anywhere between -0.91 and 1.21 percentage points.

The same trend can be observed comparing three specific subsets of the consumer price index examined in the paper. The differential between the price of a given set of services and the general price index was highest in Slovakia for passenger transport by road (11.83 percentage points) and hairdressing (7.52 percentage points), whereas in the case of restaurants and cafés (4.8 percentage points), it was second highest after Slovenia (5.02 percentage points).

The anomaly is likely to be related to the reliance of Slovakia on nominal exchange rate appreciation to drive down inflation during the qualification period for the single currency, in order to meet the Maastricht inflation criterion. This can be seen from Table 3, where the Slovak koruna appreciated by more than $11 \%$ in the period preceding entry, whereas the other new member states did not pursue nominal appreciation at all. Rapid nominal appreciation naturally leads to deflation in the prices of tradable goods, thus immediately depressing the overall inflation rate. Yet since the same mechanism does not apply to non-tradable services, in their case inflation can remain higher.

Table 3. Nominal appreciation/depreciation in the run-up to the single currency

\begin{tabular}{|l|r|r|r|r|}
\hline $\begin{array}{l}\text { Appreciation (+)/ } \\
\text { depreciation (-1) }\end{array}$ & Slovakia & Slovenia & Malta & Cyprus \\
\hline $\begin{array}{l}\text { Between 12 and 6 } \\
\text { months prior to entry }\end{array}$ & 11.2 & -0.1 & 0 & -0.9 \\
\hline $\begin{array}{l}\text { Between } 18 \text { and 6 } \\
\text { months prior to entry }\end{array}$ & 11.4 & -0.1 & 0 & -0.9 \\
\hline
\end{tabular}

Source: Author's calculations based on ECB data.

While the effects of nominal currency appreciation could on their own explain some of the unusually high divergence between the inflation of tradable and non-tradable goods in Slovakia, they fail to account for the increase in the rate of inflation we observed during the 2008-09 period with regard to non-tradables. An overheating economy could add some explanatory power, but further increases in late 2008 and the first half of 2009 - when the crisis fully hit Slovakia and unemployment was rapidly growing - make this unlikely. Therefore, there is some prima facie evidence of the effects of the changeover on the prices of non-tradables at the macro level.

\subsection{Accounting for the Balassa-Samuelson effect}

To account for the Balassa-Samuelson effect as a significant factor influencing price appreciation in the non-tradable sector, we analysed differences between the given bundle of services with the overall HICP and the individual subsets of services with the overall HICP index in three time series up to 3.5 years prior to the introduction of the euro: 18 months up to 6 months, 30 months up to 18 months, and 42 months up to 30 months prior to the euro changeover (Tables A1-A3 in the appendix). 
The tables in the appendix show that the prices in the non-tradable sector in Slovakia during the period of 1 year up to 3.5 years before introduction of the euro do not reflect any anomaly with respect to other observed countries during the same period. In Slovakia during the observed period, the differential between the prices for the bundle of services and the overall HICP was within the range of -0.94 to 1.21 . As a comparison, in the period surrounding introduction of the euro, the differential reached 4.14 percentage points. The same trend is observed comparing three specific subsets of the consumer price indices with the HICP, where the differential was within the range of -1.56 and 4.78 . As a comparison, in the period surrounding introduction of the euro, the differential reached 11.83 percentage points (in passenger transport by road). The differential between the given bundle of services, subsets of services and the overall HICP during the period surrounding introduction of the euro was significantly larger than in the observed period up to 3.5 years before the changeover. Therefore, we can conclude that the Balassa-Samuelson effect in the observed subsets of services accounts only incrementally towards price appreciation around the euro changeover. The data collected from the period up to 3.5 years before introduction of the euro support our evidence of the effects of the changeover on the prices of non-tradable sectors in Slovakia.

\subsection{Inflation perceptions vs. reality}

In this section, we examine consumer perceptions of inflation in Slovakia compared with the Czech Republic and the eurozone, and how they relate to actual inflation and to other findings in this paper.

We start with a simple chart - Figure 5 - of perceived inflation in the eurozone, the Czech Republic and Slovakia during the 2001-10 period. This indicator measures consumer experience with inflation (based on answers to the question, "How do you think that consumer prices have developed over the last 12 months?"). It is based on the overall balance among answers (there are five possible answers from "risen a lot" to "fallen"), with higher values indicating higher perceived inflation.

Figure 5. Perceived inflation in the eurozone, the Czech Republic and Slovakia, 2001-10

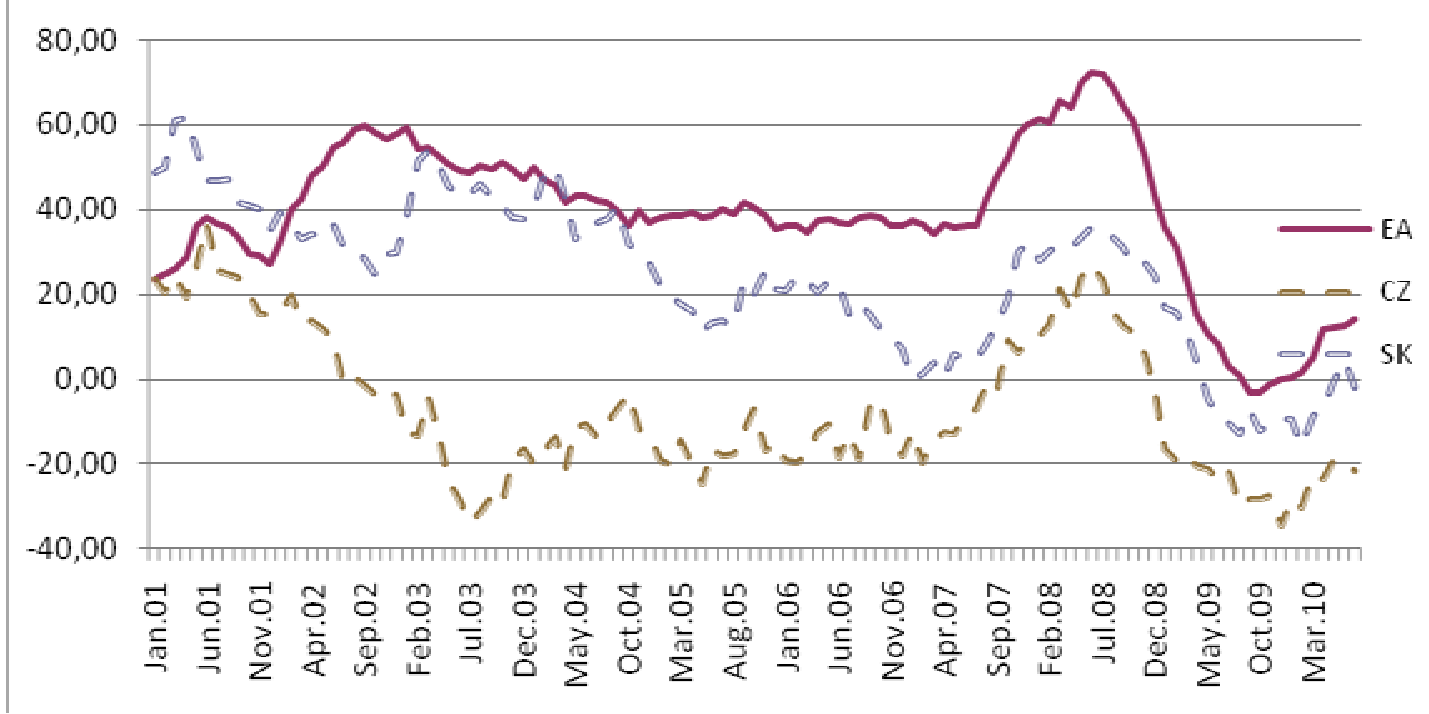

Source: Author's calculations based on European Commission data. 
The figure shows that during the last decade, level of perceived inflation has been higher in the eurozone compared with either the Czech Republic or Slovakia. The peak of perceived inflation in the eurozone coincided with euro adoption, but it continued at a relatively high level until late 2008, when a steep fall began.

The results indicate that the populations of the Czech Republic and Slovakia have a different benchmark in mind when assessing inflation in comparison with eurozone consumers. Actual eurozone inflation was either lower than or equal to Czech or Slovak inflation during nearly the entire period analysed despite perceptions indicating the opposite. Looking at the Czech and Slovak data, we can see that the 2000s were a period of declining or low perceived inflation with two exceptions:

- 2003 and early 2004 in Slovakia, when unification of VAT, an increase in excise taxes and other measures resulted in a spike in both actual and perceived inflation; and

- 2008 for both countries (as well as the eurozone), when both perceived and actual inflation rose due to an increase in commodity prices.

In other words, Slovak consumers (and Czech ones as well) held a fairly benign view of inflation even prior to euro adoption, and in the absence of major and visible price shocks, people's perceptions tracked the actual price developments quite well and tended to converge on price stability.

Based on a visual examination, one could hypothesise that perceived Slovak inflation began to move in lockstep with the eurozone (and Czech) series sometime in 2007. Indeed, analysis of 12-month correlations in the developments of Slovak prices with the eurozone and Czech prices, as depicted in Figure 6, shows that since late 2007 the correlation between Slovak prices on one hand and either of the two other price series on the other has been very high (in the 0.71.0 range).

Figure 6. Correlation of the 12-month moving sample of the Slovak HICP with the eurozone and Czech HICP, 2001-10

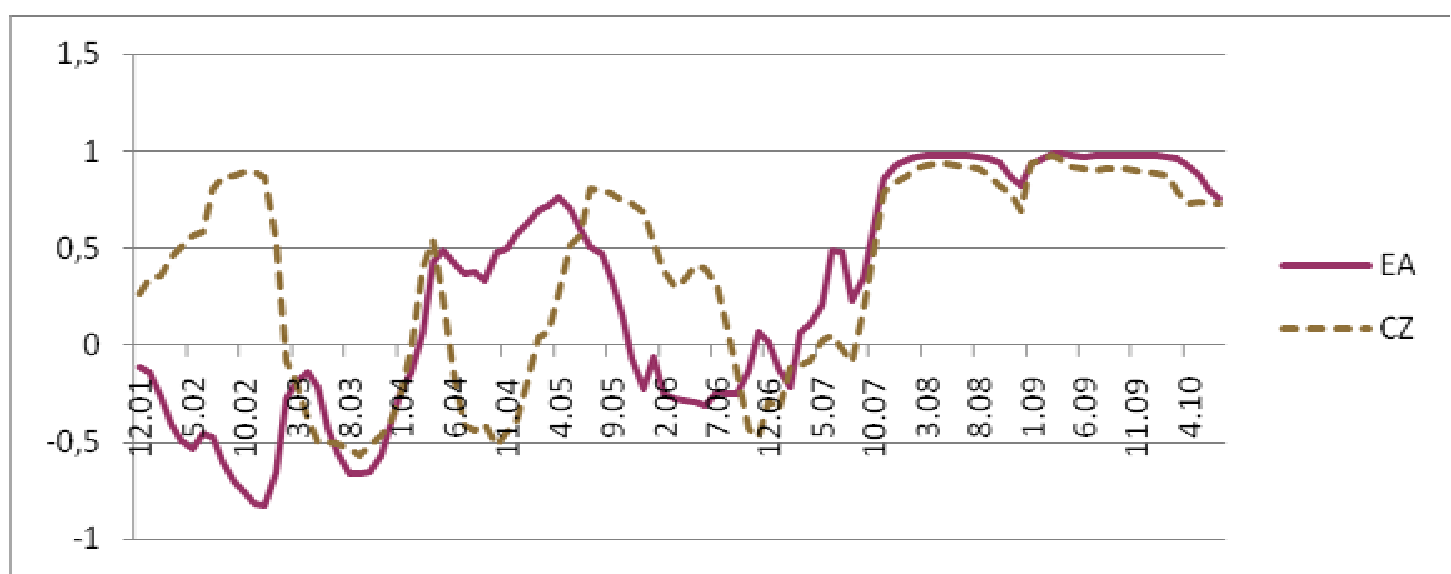

Source: Author's calculations.

Still, formal testing of the three price series shows differences in the traits of the series. While the eurozone and Czech price series are trend stationary (i.e. they are stationary after removal of a trend), the Slovak time series are not stationary (i.e. they do not revert to a mean) and there is no evidence of cointegration between the Slovak and the eurozone prices for either the entire 2001-10 period or the 2007-10 subperiod. 
To examine the developments at the time of actual entry into the eurozone, we compare perceived and actual HICP inflation during the 18 months surrounding the single currency adoption (6 months before and 12 months after). We compare four episodes -2002 , when the eurozone switched to euro bank notes and coins; 2007, when Slovenia adopted the euro; 2008, when Malta and Cyprus did (unfortunately, the relevant survey data are not available for Malta); and 2009, when Slovakia joined.

The results are shown in Table 4. We can see that there is a major difference between the eurozone (2002) and the three other countries in the correlations between actual and perceived inflation. The period before and after the introduction of euro bank notes and coins does not exhibit any correlation between actual and perceived inflation for the eurozone; meanwhile Cyprus, Slovenia and Slovakia all exhibit relatively high and positive correlations. In the case of Slovakia, this reaches an extremely high value of 0.98 .

Table 4. Perceived and actual HICP inflation in the 6 months prior to and 12 months after euro adoption

\begin{tabular}{|l|r|r|r|r|r|r|r|r|}
\hline \multirow{2}{*}{ Month } & \multicolumn{2}{|c|}{ Eurozone } & \multicolumn{2}{|c|}{ Slovakia } & \multicolumn{2}{c|}{ Cyprus } & \multicolumn{2}{c|}{ Slovenia } \\
\cline { 2 - 10 } & Perceived & Actual & Perceived & Actual & Perceived & Actual & Perceived & Actual \\
\hline$t-6$ & 36.39 & 2.55 & 33.74 & 4.43 & 34.37 & 2.34 & 13.84 & 1.93 \\
\hline$t-5$ & 35.65 & 2.35 & 33.28 & 4.44 & 42.05 & 2.24 & 23.07 & 3.12 \\
\hline$t-4$ & 33.30 & 2.16 & 30.91 & 4.55 & 36.00 & 2.34 & 19.20 & 2.47 \\
\hline$t-3$ & 29.65 & 2.25 & 27.27 & 4.18 & 47.01 & 2.7 & 22.95 & 1.54 \\
\hline$t-2$ & 28.89 & 1.97 & 27.58 & 3.9 & 51.64 & 3.2 & 13.83 & 2.43 \\
\hline$t-1$ & 27.27 & 2.05 & 24.54 & 3.54 & 43.99 & 3.74 & 16.24 & 2.98 \\
\hline$t$ & 32.05 & 2.61 & 16.72 & 2.71 & 38.93 & 4.07 & 26.56 & 2.79 \\
\hline$t+1$ & 40.16 & 2.52 & 15.88 & 2.39 & 45.19 & 4.74 & 29.00 & 2.28 \\
\hline$t+2$ & 42.41 & 2.50 & 11.58 & 1.8 & 49.39 & 4.44 & 22.58 & 2.63 \\
\hline$t+3$ & 47.90 & 2.30 & 4.46 & 1.38 & 41.19 & 4.35 & 24.70 & 2.86 \\
\hline$t+4$ & 50.19 & 2.02 & -4.56 & 1.07 & 60.73 & 4.64 & 29.86 & 3.1 \\
\hline$t+5$ & 54.64 & 1.92 & -8.64 & 0.72 & 67.54 & 5.21 & 34.52 & 3.77 \\
\hline$t+6$ & 55.74 & 2.02 & -10.11 & 0.61 & 68.47 & 5.34 & 33.53 & 3.97 \\
\hline$t+7$ & 58.98 & 2.12 & -13.02 & 0.49 & 70.40 & 5.07 & 54.51 & 3.43 \\
\hline$t+8$ & 59.91 & 2.10 & -7.65 & 0.05 & 67.12 & 4.99 & 60.83 & 3.57 \\
\hline$t+9$ & 57.97 & 2.30 & -12.26 & -0.13 & 66.98 & 4.84 & 72.05 & 5.11 \\
\hline$t+10$ & 56.54 & 2.29 & -10.70 & 0.04 & 62.56 & 3.13 & 74.85 & 5.74 \\
\hline$t+11$ & 57.56 & 2.28 & -9.58 & 0.04 & 56.51 & 1.82 & 77.40 & 5.7 \\
\hline Correlation & -5.24 & - & 0.98 & - & 0.60 & & 0.88 \\
\hline
\end{tabular}

Note: $t$ is the first month of euro adoption, in practice January of the year of adoption.

Source: Author's calculations based on European Commission data. 
If one compares only perceived inflation, however, there is a high level of correlation between values for the eurozone, Cyprus and Slovenia ( 0.8 and higher) and a strong negative correlation between these series and perceived inflation in Slovakia (-0.8 and lower). This indicates that the stylised inflation experience around the time of adoption is one of growing inflation and that Slovakia is an outlier in this stylised picture.

These findings lead to the following simple typology of the relationship between actual and perceived inflation in the period surrounding euro adoption, shown in Table 5.

Table 5. Actual and perceived inflation in the period of euro adoption: Cyprus, the eurozone, Slovakia and Slovenia

\begin{tabular}{|l|l|l|}
\hline Actual/perceived inflation & Low & High \\
\hline Low & Slovakia & Eurozone \\
\hline High & - & Cyprus, Slovenia \\
\hline
\end{tabular}

Source: Author.

In this simplified version, the original euro area experienced low actual and high perceived inflation, Cyprus and Slovenia experienced high actual and high perceived inflation, and Slovakia experienced low actual and low perceived inflation.

To summarise, inflation as perceived by Slovak consumers has generally been on a downward path during the last decade (with a few exceptions based on exogenous shocks) and euro adoption has not changed this. On the contrary, Slovaks exhibit an extremely high correlation between the actual disinflation during the period surrounding the changeover and their perceptions of declining inflation. This sets them apart from other countries adopting the single currency, which all experienced an increase in perceived inflation during the same period, regardless of whether actual inflation conformed to the same trend.

\subsection{Analysis of the price data at the micro level and comparison with national price data}

In this section, we present an analysis of the price data for selected services collected at the level of individual enterprises in Bratislava and Brno. The point of the analysis is to see whether any anomalies can be observed during the euro adoption period in Bratislava, and to subsequently examine the fit between enterprise-level prices and national price data for similar categories. From this, conclusions are drawn about the impact of the changeover to the euro on these prices in Slovakia.

The data presented are summary statistics and the results of some basic tests done with the series. For each item, Table 6 presents the following information:

- $\quad$ the mean increase in the price between July 2008 and July 2009;

- $\quad$ a test of whether we can reject the hypothesis (Ho) of identical means for the Bratislava and Brno series, i.e. confirmation that they are statistically different;

- the variance in the increase of the price, i.e. the dispersal of the price changes; and

- $\quad$ a test of whether we can reject the hypothesis (Ho) of identical variance for the Bratislava and Brno series, i.e. confirmation that they are statistically different. 
Table 6. Summary statistics for datasets measuring changes in the prices of selected services in Bratislava and Brno between July 2008 and July 2009

\begin{tabular}{|c|c|c|c|c|c|}
\hline Service & City & $\begin{array}{l}\text { Mean = } \\
\text { inflation }\end{array}$ & $\begin{array}{l}\text { Reject Ho of } \\
\text { identical } \\
\text { means = } \\
\text { inflation rates }\end{array}$ & Variance & $\begin{array}{l}\text { Reject Ho of } \\
\text { identical } \\
\text { variance } \\
\text { (dispersion of } \\
\text { inflation) }\end{array}$ \\
\hline \multirow[b]{2}{*}{ Schnitzel } & Bratislava & 4.38679 & \multirow[b]{2}{*}{ No } & 60.7554 & \multirow[b]{2}{*}{ Yes } \\
\hline & Brno & 5.11667 & & 127.395 & \\
\hline \multirow[b]{2}{*}{ Boiled potatoes } & Bratislava & 9.13455 & \multirow{2}{*}{ No } & 466.466 & \multirow[b]{2}{*}{ Yes } \\
\hline & Brno & 8.97333 & & 229.235 & \\
\hline \multirow[b]{2}{*}{ Cappuccino } & Bratislava & 5.04364 & \multirow{2}{*}{ No } & 99.4436 & \multirow[b]{2}{*}{ No } \\
\hline & Brno & 4.20667 & & 74.9806 & \\
\hline \multirow[b]{2}{*}{ Viennese coffee } & Bratislava & 4.50909 & & 71.9001 & \multirow[b]{2}{*}{ No } \\
\hline & Brno & 5.35333 & No & 79.3881 & \\
\hline \multirow[b]{2}{*}{ Woman's haircut } & Bratislava & -0.309375 & & 2557.08 & \multirow[b]{2}{*}{ Yes } \\
\hline & Brno & 3.45455 & No & 234.293 & \\
\hline \multirow{2}{*}{$\begin{array}{l}\text { Taxi - basic } \\
\text { charge }\end{array}$} & Bratislava & 82.0762 & & 15061.9 & \multirow[b]{2}{*}{ Yes } \\
\hline & Brno & 5.12308 & Yes & 156.382 & \\
\hline \multirow[b]{2}{*}{ Taxi $-1 \mathrm{~km}$} & Bratislava & 21.5667 & & 2302.79 & \multirow[b]{2}{*}{ Yes } \\
\hline & Brno & 1.73077 & Yes & 126.452 & \\
\hline \multirow{2}{*}{$\begin{array}{l}\text { Taxi - } 1 \text { min } \\
\text { waiting }\end{array}$} & Bratislava & 9.5 & & 333.816 & \multirow[b]{2}{*}{ No } \\
\hline & Brno & 7.68462 & No & 213.248 & \\
\hline
\end{tabular}

Note: Rejection/non-rejection of the Ho is assessed at the $10 \%$ probability level.

Source: Author. 
For cafés and restaurants, we examined four items: a main course (schnitzel), a side dish (boiled potatoes) and two types of coffee. The micro data show nearly identical developments in Bratislava and Brno, with inflation broadly in the $4-5 \%$ range (with boiled potatoes showing higher inflation at 9\%). The dispersion of the prices differs for only two of the four items, notably each time in a different direction. Overall, in this category there clearly does not appear to be any difference between the two cities in the mean, but there is a statistically significant difference in the variance for the meals - schnitzel and boiled potatoes - as shown in Table 6.

Table 7 therefore presents a detailed frequency distribution of the price changes in the two cities for these commodities. In the case of schnitzel, we can observe that the difference in price distribution lies mainly in the fact that Bratislava had a much higher frequency of small to moderate price changes than Brno and very few price decreases, resulting in a higher percentage of upward price changes than Brno: $45 \%$ vs. $30 \%$.

Table 7. Distribution of price changes for schnitzel and boiled potatoes, Bratislava and Brno (\%)

\begin{tabular}{|l|r|r|r|r|}
\hline \multirow{2}{*}{} & \multicolumn{2}{|c|}{ Schnitzel } & \multicolumn{2}{c|}{ Boiled potatoes } \\
\cline { 2 - 5 } & Bratislava & Brno & Bratislava & Brno \\
\hline Decrease & 3.77 & 13.33 & 1.81 & 0 \\
\hline No change & 50.94 & 56.67 & 62.27 & 66.67 \\
\hline 0 to 10 & 26.41 & 6.67 & 3.63 & 3.33 \\
\hline 10 to 20 & 15.09 & 6.67 & 16.36 & 10 \\
\hline 20 to 30 & 1.89 & 13.33 & 3.63 & 6.67 \\
\hline 30 to 40 & 1.89 & 0 & 5.45 & 6.67 \\
\hline Above 40 & 0 & 3.33 & 1.81 & 6.67 \\
\hline
\end{tabular}

Note: Rejection/non-rejection of the Ho is assessed at the $10 \%$ probability level.

Source: Author.

For the prices of women's haircuts, there is a similar finding. Here we use only one dataset, but in this case the data for Bratislava exhibit much greater variance, including the unparalleled experience of a majority of establishments in Bratislava cutting their prices, as shown in Table 8.

Table 8. Distribution of price changes for a woman's haircut, Bratislava and Brno (\%)

\begin{tabular}{|l|r|r|}
\hline & Bratislava & Brno \\
\hline Decrease & 40.63 & 8.7 \\
\hline No change & 15.63 & 47.83 \\
\hline 0 to 10 & 18.75 & 8.7 \\
\hline 10 to 20 & 3.13 & 21.74 \\
\hline 20 to 30 & 3.13 & 4.35 \\
\hline 30 to 40 & 9.38 & 4.35 \\
\hline Above 40 & 9.38 & 4.35 \\
\hline
\end{tabular}

Source: Author.

In the case of taxi prices, however, the difference between the two cities is statistically significant, both in the increase in mean prices and in the variance for two of the three items in this category. Bratislava taxi drivers obviously took advantage of the 2008-09 period in terms of what they were charging - with more than an $82 \%$ jump in the basic charge and a $21 \%$ increase in the price per $1 \mathrm{~km}$. Nothing of this kind happened in Brno during the same period. 
In addition to the data collected for every dataset, we also look at the overall frequency of changes in all datasets combined. As shown in Table 9, during the period between July 2008 and July 2009, prices in Brno were much more stable than in Bratislava. In Brno, $65 \%$ of prices did not change at all, whereas in Bratislava this was true for less than $50 \%$ of prices. This is a result of higher rates of changes in Bratislava in both directions, as the table shows.

Table 9. Frequency distribution of all price changes in the micro dataset

\begin{tabular}{|l|r|r|}
\hline & Bratislava & Brno \\
\hline Decrease & 8.63 & 3.85 \\
\hline No change & 49.84 & 64.84 \\
\hline 0 to 10 & 14.7 & 7.69 \\
\hline 10 to 20 & 13.74 & 9.89 \\
\hline 20 to 30 & 3.51 & 6.59 \\
\hline 30 to 40 & 3.83 & 4.95 \\
\hline Above 40 & 5.75 & 2.2 \\
\hline
\end{tabular}

Source: Author.

In the concluding analysis of this section, we compare the data collected at the enterprise level with the official HICP data collected for similar categories. We examine whether similar developments can be observed at both levels, and if not, whether the discrepancies might have occurred as a result of the collection process, more specifically whether the data might have been skewed in that process.

Table 10 thus compares mean price increases for individual items with HICP inflation in the relevant category for the period between July 2008 and July 2009.

Table 10. Comparison of enterprise level inflation data for Bratislava and Brno with national inflation data, y-o-y change, July 2009

\begin{tabular}{|c|c|c|c|c|}
\hline \multirow[t]{2}{*}{ Item } & \multicolumn{2}{|c|}{ Bratislava inflation } & \multicolumn{2}{|c|}{ Brno inflation } \\
\hline & Mean & $\begin{array}{r}95 \% \text { Confidence } \\
\text { interval }\end{array}$ & Mean & $\begin{array}{r}95 \% \text { Confidence } \\
\text { interval }\end{array}$ \\
\hline Schnitzel & 4.38679 & 2.23834 to 6.53524 & 5.11667 & .90205 to 9.33128 \\
\hline Boiled potatoes & 9.13455 & 3.29583 to 14.9733 & 8.97333 & 3.31977 to 14.6269 \\
\hline Cappuccino & 5.04364 & 2.34779 to 7.73948 & 4.20667 & 0.973292 to 7.44004 \\
\hline Viennese coffee & 4.50909 & 2.21679 to 6.80139 & 5.35333 & 2.02628 to 8.68038 \\
\hline $\begin{array}{l}\text { HICP cafés, } \\
\text { restaurants, etc. }\end{array}$ & 9.49 & - & 4.71 & - \\
\hline Haircut & -0.309375 & -18.5409 to 17.9222 & 3.45455 & -3.33204 to 10.2411 \\
\hline $\begin{array}{l}\text { HICP hair salons, } \\
\text { etc. }\end{array}$ & 13.66 & - & 7.84 & - \\
\hline Taxi-basic charge & 82.0762 & 26.2115 to 137.941 & 5.12308 & -2.43379 to 12.6799 \\
\hline Taxi - 1km & 21.5667 & $\begin{array}{r}-0.276921 \text { to } \\
43.4103\end{array}$ & 1.73077 & -5.06458 to 8.52612 \\
\hline Taxi - 1 min waiting & 9.5 & -1.1399 to 16.5091 & 7.68462 & 1.18331 to 17.8167 \\
\hline $\begin{array}{l}\text { HICP passenger } \\
\text { transport by road }\end{array}$ & 15.79 & - & 2.83 & - \\
\hline
\end{tabular}

Source: Author for non-HICP data, Eurostat for HICP data 
To understand and interpret the table, two caveats are in order. First of all, the individual items are only a fraction of the relevant HICP category and might not include the specific items picked by the national statistical authorities for their surveys. For example, in the Czech statistical index, the cost of a taxi comprises only a small part of the consumer prices for passenger transport by road, which is dominated by public transport. Similarly, the cost of schnitzel is only a small percentage of restaurant and café costs, there is only one type of coffee included and boiled potatoes are not included. For haircuts, a woman's haircut as defined for our purposes is only one of three items included in the relevant HICP category. ${ }^{2}$ Second, there might be regional differences in prices, so the mismatch between national HICP prices and the micro data for Bratislava and Brno could reflect these rather than any mistakes.

Thus we can only note any major discrepancies between the micro and macro price data. In the case of restaurant/café prices, the price increases at the micro and macro levels do not exhibit an obvious discrepancy. In the case of haircuts, the HICP prices and micro prices for Bratislava are rather different, with enterprise-level prices showing a deflation. Yet given the wide dispersal of prices, it is not possible with certainty to state that the inflation measured for the micro data differs from HICP data. For taxi prices, the basic charge in Bratislava is obviously out of line with HICP prices, but that is of limited value in itself as it is only a part of the overall taxi price. Nonetheless, in the case of taxi prices, we can come closest to stating with confidence that the Bratislava micro data differ significantly from the national data.

\section{Conclusion}

This paper has looked at the Slovak experience with euro adoption from the point of view of perceived versus actual inflation and with a focus on a specific set of non-tradable prices. It has examined whether Slovak consumers experienced or perceived (or both) an unusual price jump at the time of euro adoption and what could be the possible explanations for such a phenomenon, building on the literature concerning previous instances of switches to the single currency. It has utilised both macro-level inflation data and an original dataset of enterpriselevel data for specific non-tradables and compared Slovakia not just with the eurozone, but also with the Czech Republic - a country with a similar economic policy and inflation history, but which has not joined the single currency.

Our findings can be divided roughly into three groups: developments in actual inflation at the macro level, developments in perceived inflation at the macro level and conclusions concerning enterprise-level prices for selected non-tradables that have been most prone to perceived inflation in previous changeovers to the single currency.

At the macro price level, we found that in Slovakia, the divergence between the prices of tradables and non-tradables became much starker in the period of euro adoption compared with other countries. This finding concerns all services, but even more emphatically the kinds of nontradables on which the paper has focused. The anomaly can be most plausibly explained by the reliance of Slovakia on nominal exchange rate appreciation to drive down inflation during the qualification period for the single currency. But even though this can account for some of the divergence between the inflation of tradable and non-tradable goods in Slovakia, it is unlikely to account for all of it. Therefore, there is some prima facie evidence of the effects of the changeover on the prices of non-tradables at the macro level.

Looking at perceptions of inflation, Slovak consumers appear to be much more accustomed to inflation shocks and ceteris paribus have taken a much more benign view of inflation compared with other eurozone countries. We have developed a simple typology of inflation perception/reality during the changeover, in which the original euro area experienced low actual

\footnotetext{
${ }^{2}$ We could not obtain access to the detailed structure of the Slovak HICP.
} 
and high perceived inflation, Cyprus and Slovenia experienced high actual and high perceived inflation, and Slovakia experienced low actual and low perceived inflation. Slovaks exhibited an extremely high correlation between the actual disinflation during the period surrounding the changeover and their perceptions of declining inflation. This accurate perception of real inflation sets the Slovaks apart from other countries adopting the single currency, which all experienced an increase in perceived inflation during the same period regardless of whether actual inflation conformed to the same trend.

With regard to micro-level prices, the micro data show that while the mean price increases in Bratislava and its Czech control city Brno are generally indistinguishable (with the exception of taxis, for which Bratislava experienced a huge price increase), Bratislava experienced a much greater variance in price changes. In Brno, $65 \%$ of prices did not change at all, whereas in Bratislava this was true for less than $50 \%$ of prices. This is a result of higher rates of changes in Bratislava in both directions.

Our findings point to the following conclusions:

- In terms of both reality and perceptions of general price movements, every adoption is different.

- For Slovakia, euro adoption came at a time of disinflation, which consumers actually experienced, so there does not seem to be any overall 'teuro' perception.

- We can nonetheless observe high inflation for non-tradables at both the macro and micro levels, linked not only to the Slovak strategy of nominal currency appreciation prior to eurozone entry but also to the changeover itself. In addition there is evidence of greater variance in the prices of non-tradables in Bratislava at the time. 


\section{References}

Altissimo, F., M. Ehrman and F. Smets (2006), Inflation Persistence and Price-setting Behaviour in the Euro Area: A Summary of the IPN Evidence, ECB Occasional Paper Series No. 46, ECB, Frankfurt, June.

Badarinza, C. and M. Buchmann (2009), Inflation Perception and the Expectations in the Euro Area: The Role of the News, ECB Working Paper Series No. 1088, ECB, Frankfurt, September.

Brachinger, H.W. (2004), "Euro gleich Teuro: Wahrgenommene versus gemessene Inflation", Presentation at Statistik Austria, Vienna, 28 October.

(2005a), "Euro gleich Teuro: Wahrgenommene versus gemessene Inflation", in G. Greulich, M. Lösch, C. Müller and W. Stier (eds), Empirische Konjunktur- und Wachstumsforschung, Festschrift für Bernd Schips zum 65, Geburtstag, Zürich: Rüegger, pp. 8-28.

(2005b), "Measuring Perceived Inflation: A Prospect Theory Approach", Extended abstract, International Statistical Institute $55^{\text {th }}$ Session, Sydney, 5-12 April.

(2006), Euro or 'Teuro'?: The Euro-induced Perceived Inflation in Germany, Department of Quantitative Economics Working Paper No. 5, University of Fribourg, Switzerland.

Ercolani, M.G. and J. Dutta (2007), "The Impact of the Euro Changeover on Inflation: Evidence from the Harmonised Index of Consumer Prices", in D. Cobham (ed.), The Travails of the Eurozone, Basingstoke: Palgrave Macmillan.

Egert, B. and J. Podpiera (2008), "Beyond Balassa-Samuelson in Visegrad-4 Countries”, Policy Insight No. 20, Centre for Economic Policy Research, London, 2 April (www.voxue.org/index).

Fabiani, S., M. Druant, I. Hernando, C. Kwapil, B. Landau, C. Loupias, F. Martins, T.Y. Mathä, R. Sabbatini, H. Stahl and A.C.J. Stokman (2005), The Pricing Behaviour of Firms in the Euro Area: New Survey Evidence, ECB Working Paper No. 535, ECB, Frankfurt, September.

Hüfner, F. and I. Koske (2008), The euro changeover in the Slovak Republic: implications for inflation and interest rates, OECD Economics Department Working Paper No. 632, OECD, Paris.

Kirchler, E. (2005), "Comment on 'Perceived Inflation and the Euro: Why High? Why Persistent?", Price Setting and Inflation Persistence in Austria, Proceedings of OeNB Workshops, No. 8, Oesterreichische Nationalbank, Vienna.

Mastrobuoni, G. (2004), The Effects of the Euro-Conversion on Prices and Price Perceptions, CEPS Working Document No. 101, CEPS, Brussels.

Stix, H. (2005), Perceived Inflation and the Euro: Why High? Why Persistent?, Price Setting and Inflation Persistence in Austria, Proceedings of OeNB Workshops, No. 8, Oesterreichische Nationalbank, Vienna. 


\section{Appendix}

Table A1. Inflation in selected areas, in the July 18 months and the July 6 months prior to euro adoption

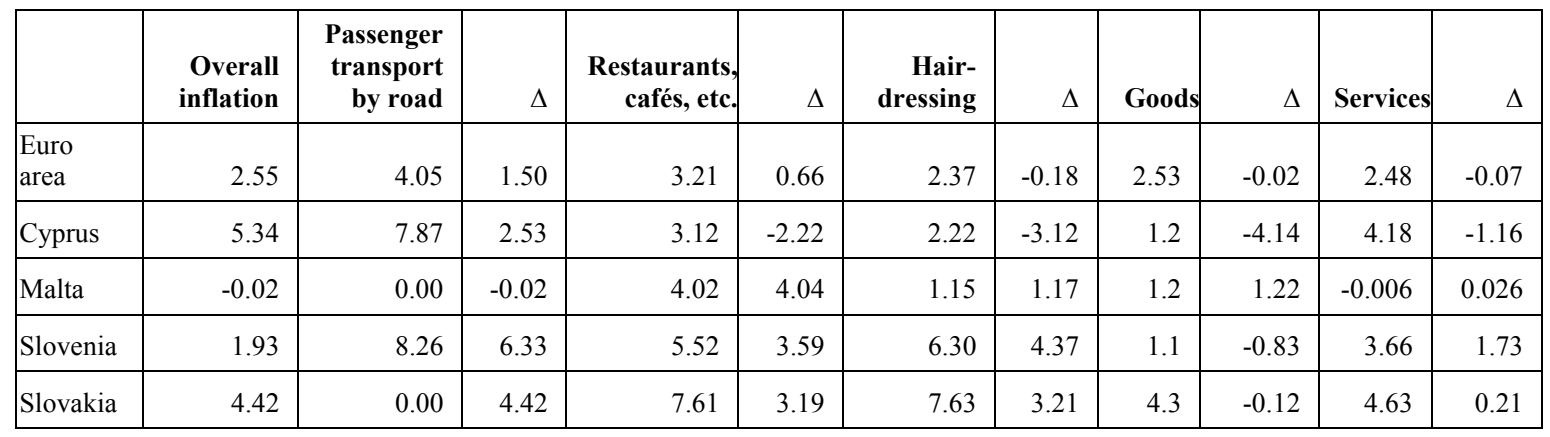

Source: Author's calculations based on Eurostat data.

Table A2. Inflation in selected areas, in the July 30 months and the July 18 months prior to euro adoption

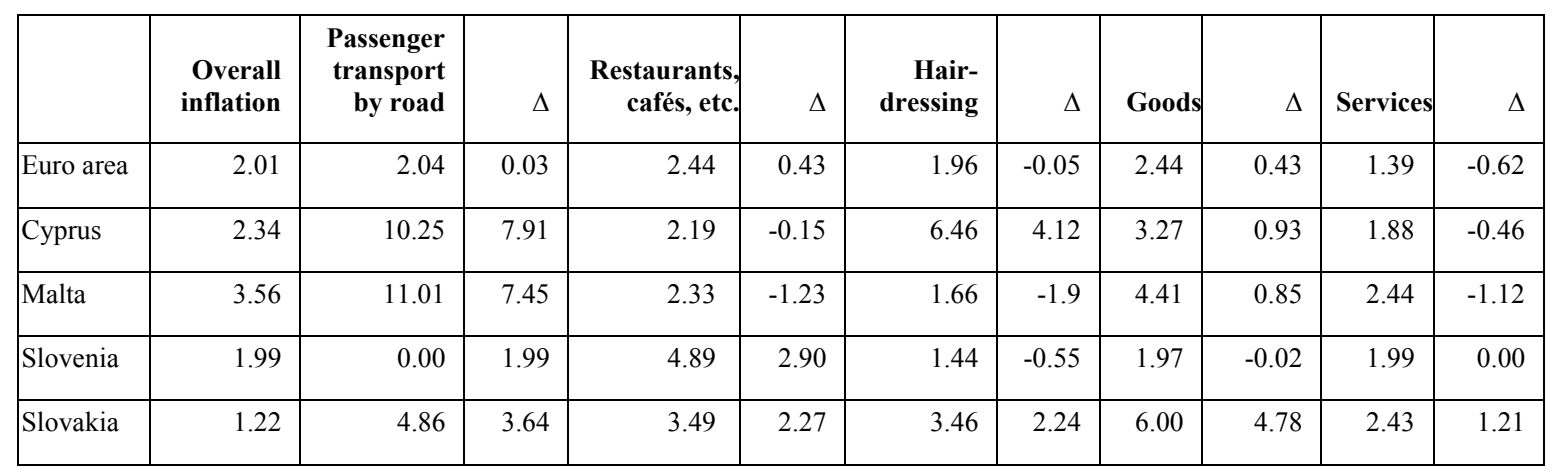

Source: Author's calculations based on Eurostat data.

Table A3. Inflation in selected areas, in the July 42 months and the July 30 months prior to euro adoption

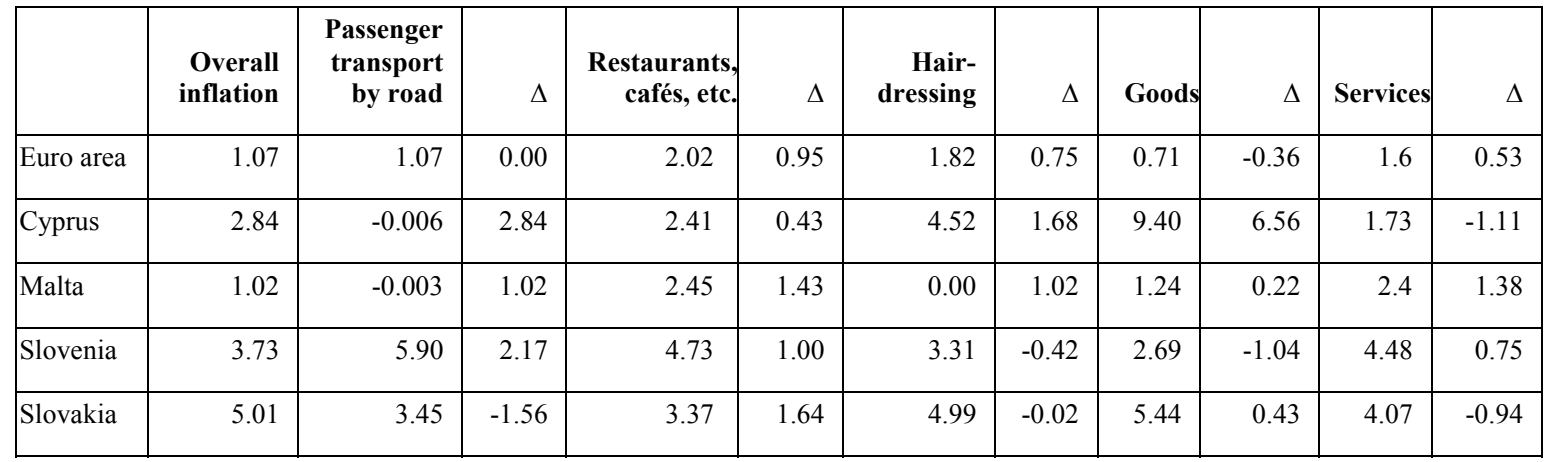

Source: Author's calculations based on Eurostat data. 


\section{About CE
Programme Structure}

Founded in Brussels in 1983, the Centre for European Policy Studies (CEPS) is among the most experienced and authoritative think tanks operating in the European Union today. CEPS serves as an leading forum for debate on EU affairs, but its most distinguishing feature lies in its strong in-house research capacity, complemented by an extensive network of partner institutes throughout the world.

\section{Goals}

- To carry out state-of-the-art policy research leading to solutions to the challenges facing Europe today.

- To achieve high standards of academic excellence and maintain unqualified independence.

- To act as a forum for discussion among stakeholders in the European policy process

- To provide a regular flow of authoritative publications offering policy analysis and recommendations.

- To build collaborative networks of researchers, policy-makers and business representatives across the whole of Europe.

- To disseminate our findings and views through our publications and public events.

\section{Assets}

- Multidisciplinary, multinational \& multicultural research team.

- Complete independence to set its own research priorities and freedom from any outside influence.

- Seven research networks, comprising numerous other highly reputable institutes, to complement and consolidate CEPS' research expertise and to extend its outreach.

- An extensive membership base of Corporate and Institutional Members, which provide expertise and practical experience and act as a sounding board for CEPS policy proposals.

\section{Research Programmes}

- $\quad$ Economic \& Social Welfare Policies

- $\quad$ Financial Markets \& Institutions

- $\quad$ Energy \& Climate Change

- Regulatory Policy

- $\quad$ EU Foreign, Security \& Neighbourhood Policy

- $\quad$ Justice \& Home Affairs

- $\quad$ Politics \& Institutions

- $\quad$ Agricultural \& Rural Policy

\section{Research Networks}

- $\quad$ European Capital Markets Institute (ECMI)

- $\quad$ European Climate Platform (ECP)

- $\quad$ European Credit Research Institute (ECRI)

- $\quad$ European Network for Better Regulation (ENBR)

- $\quad$ European Network of Economic Policy Research Institutes (ENEPRI)

- $\quad$ European Policy Institutes Network (EPIN)

- $\quad$ European Security Forum (ESF)

CEPS organises a variety of activities, involving its members and other stakeholders in the European policy debate, including national and EU-level policy-makers, academics, corporate executives, NGOs and the media. Its funding is obtained from a variety of sources, including membership fees, project research, foundation grants, conferences fees, publication sales and an annual grant from the European Commission.
E-mail: info@ceps.eu

Website: www.ceps.eu 